Arab World English Journal (AWEJ) Volume 12. Number3 September 2021

DOI: https://dx.doi.org/10.24093/awej/vol12no3.9

Pp. $129-143$

\title{
Using Advance Organizer Model to Influence the Meaningful Learning of New Concepts for ESL Learners in a Collaborative Classroom
}

\author{
Piyawan Sunasuan \\ Mahidol University International Demonstration School \\ Nakhon Pathom, Thailand
}

Ubonwan Songserm

Faculty of Education, Silpakorn University

Nakhon Pathom, Thailand

Received: 7/18/2021

Accepted: $8 / 21 / 2021$

Published: 9/24/2021

\section{Abstract}

This research attempted to study how using an advance organizer model can influence meaningful learning of new concepts for ESL learners in collaborative classrooms. The objectives were 1) to study the effects of using the advance organizer model, and 2) to study the student achievement after using the advance organizer model to compare to the 80 percent criterion. The study sample is purposively limited to 20 students in a class of the Introduction to Skills for Leadership and Management at Mahidol University International Demonstration School, Thailand. Post-test and observation forms were used as research tools. The data were analyzed by content analysis, mean and standard deviation. The findings revealed that 1) The effects occurred in both instructional and nurturant effects. The students engaged effectively in learning and acquiring information. Students discussed and exchanged information using existing knowledge and experiences to connect and explain the ideas to others. The instructional design also meets the steps of the advance organizer model. The teacher designed the tasks of learning follows the three phases of the advance organizer format. 2) The student achievement after using the model to meet the criteria of 80 . This study reflects that the model can influence meaningful learning of new concepts and improve academic achievements for ESL learners in collaborative classrooms. However, few researchers have addressed the problem of collaborative learning in large courses. Hence, further study should focus on implementing the model with higher numbers of students to confirm its effectiveness.

Keywords: advance organizer model, collaborative classroom, ESL learners, meaningful learning of new concepts

Cite as: Sunasuan, P., \& Songserm, U. (2021). Using Advance Organizer Model to Influence the Meaningful Learning of New Concepts for ESL Learners in a Collaborative Classroom . Arab World English Journal, 12 (3) 129 -143. DOI: https://dx.doi.org/10.24093/awej/vol12no3.9 


\section{Introduction}

Collaborative classrooms focus on the shared knowledge among teachers and students (Tinzmann et al., 1990). The teachers work as mediators to facilitate the students to learn, while students work together to complete tasks using critical processes. Tinzmann et al. (1990) suggest that a collaborative classroom could provide effective communication among students and influence them to be successful learners. According to Tan, Gallo, Jacobs, and Lee (1999), collaborative learning can cultivate students' thinking skills, including creativity and information technology skills. While students exchange information among peers, they can also interact through the processes of brainstorming, discussing, explaining, and persuading. Collaborative learning empowers the learners to gain higher achievement, engagement with school, inter-ethnic relations, self-esteem, enjoyment, and thinking skills (Johnson \& Johnson, 1989; Cohen, 1994; Slavin, 1995). It is highly versatile and can be used to achieve several critical educational objectives. Collaboration among learners can enhance the learning experience (Brown, 2001).

Over a decade, collaborative learning has emerged in ESL (English as a Second Language) education as a significant concept and instructional practice. A study from Liang, Mohan, and Early (1998) about collaborative learning in ESL classes has found that many researchers suggested that collaborative learning effectively maximizes second language acquisition. It provides opportunities for both language input and output from the interaction, which enhances language proficiency. Moreover, collaborative learning claims to help ESL learners to draw on their primary language resources as they develop second language skills.

However, Liang et al. (1998) have found some issues from most research on cooperative learning. Even though teachers can collaboratively interact with students to support their learning, students may find themselves struggling with tremendous cultural adjustments to adapt to the collaborative course format. The ESL students, who come from teacher-centered educational backgrounds, may have conflicts between the new and old experiences and beliefs. The most prominent concern is that there was little attention on the quality of student academic discourse development. Following research carried out by Shafie, Maesin, Osman, Nayan, and Mansor (2010), collaborative working creates a stressful learning environment among ESL learners due to poor language knowledge. Moreover, undeveloped social skills can be weaknesses in acquiring new vocabularies and block them from constructing new meaningful knowledge.

Shafie et al. (2010) argue that well-organized collaborative tasks can motivate students to work comfortably with others and enhance creativity and following output. Sharan (2015) also indicates that the interaction between teachers and students and among students can create a collaborative classroom where students ask questions, share ideas and understanding, and construct meaningful knowledge.

Following the Independent Committee for Education Reform (ICER) (2019), Thai educational standards are lower than international standards. It focuses on content-based learning 
and memorization. The Ordinary National Education Test (ONET) result among Thai high school students has been continually low for more than ten years. In the year 2018, most of the students failed, with the average scores on each subject were under 50 percent. The ICER has cited that one reason which hinders students from improving their learning is learning management in the classroom. Students learned to be passive learners who emphasize memorization and lack critical thinking and creativity. The teachers still focus on the summative assessment and ignore the meaningful learning of the lesson to meet the learning objectives. Following Luther (2000), teacher-centered teaching mainly focused on the summative assessment on students' ability to remember and understand the contents taught by their teachers.

In September 2019, Mahidol University International Demonstration School surveyed the Language learning experiences of the students who mostly are Thai native speakers. The survey aimed to understand the students' difficulties in content comprehensive understanding as being ESL learners. The study was from 422 participants. It revealed that $43 \%$ of them encounter gaps in their English knowledge that stops them from understanding the lessons a few times a week. Onefifth of them said most days. Followed by $34 \%$ said there are more than 10 English words per day they do not quite understand. One-third of the students said they know $50-75 \%$ of the instructional language, while $5 \%$ said they only understand it at $25-50 \%$. It reflected some considerable amounts of the struggling in language learning that blocked them from learning of meaningful context as they are ESL learners. The practical learning pedagogy like this is not learning the language of English for only communicative purposes. It could enhance the understanding of the subject content meaningfully as well.

Meaningful learning is from the subsumption theory of Ausubel. Ausubel (1962) mentions that creating meaningful verbal learning, deals with three concerns: 1) how is knowledge (content) organized, 2) how the cognitive structure works to construct new concepts of information (learning), and 3) how teachers can implement the ideas about the content and learning when presenting new materials to students (instruction). He believes that students do not have to discover generalizations or concepts without understanding them meaningfully. Ausubel (1968) classifies meaningful verbal learning into three concepts. There are subordinate learning, superordinate learning, and combinatorial learning.

Using advance organizers to design presentations is suggested by Ausubel (1968), who favors the improvement of presentational models of teaching (Joyce, Weil, \& Calhoun, 2015; Sirithanyarat \& Laoriendee, 2019). It mainly refers to direct empirical and nonverbal contact with the data. Although it concerns passive learning, a well-organized presentation can work as an intellectual scaffolding (Ausubel, 1968). He develops the Advance Organizer Model and suggests that students can construct their knowledge in parallel with meaningful learning of the subject matter, the way it organizes. The model emphasizes logical operation to enhance the retention of new information (Joyce et al., 2015; Sirithanyarat \& Laoriendee, 2019). 
To summarize, influencing meaningful learning of concepts among ESL learners is significant. Apart from encouraging collaborative learning in the classroom, the well-organized task to scaffold student thinking is imperative. The advance organizer model of Ausubel is different from the discovery learning methods. They, instead, support both discovery and expository techniques. Moreover, Ausubel suggests that the structural concepts in this information-processing model suit junior high school age (Ausubel, 1962).

Hence, the main aim of this research was to study the effects of using advance organizers to influence the meaningful learning of concepts for ESL learners in collaborative classrooms. The research question was "how using an advance organizer model can influence the meaningful learning of new concepts for ESL learners in collaborative classrooms?." Two research objectives were as follows :

1. To study the effects of using the advance organizer model

2. To study the student achievement after using the advance organizer model to compare to the 80 percent criterion

\section{Literature Review \\ Collaborative Classrooms}

Collaborative Classrooms address sharing knowledge and authority to allow the changing relationships between teachers and students (Tinzmann et al., 1990; Ibrahim et al., 2015). The teacher's role in mediating learning characterizes teachers' new approaches to instruction. Emphasizing heterogeneous groups of students addresses the composition of collaborative classrooms (Tinzmann et al., 1990). Collaborative classrooms suggest focusing on teacher's facilitation, using appropriate materials, individual accountability, positive independence, effective communication, interpersonal skills among and within groups, real-time interaction, and group processing (Ibrahim et al., 2015).

Four essential characteristics of collaborative classrooms create meaningful learning in classrooms (Tinzmann et al., 1990); 1) share knowledge among teachers and students, 2) share authority among teachers and students, 3 ) teachers as mediators and 4) heterogeneous groupings of students.

\section{Shared Knowledge among Teachers and Students}

In a collaborative classroom, teachers should share knowledge and shared goals with students. Meanwhile, the students can share knowledge with their peers. The teachers should clarify the objectives of a particular activity and facilitate students to contribute ideas. By sharing knowledge, students could share experiences and ideas with others. It empowers students to explore more perspectives and solutions to problems. Moreover, the students would also be motivated to pay more attention (Tinzmann et al., 1990; Ibrahim et al., 2015). However, it needs to be aware that the students might have conflicts easily due to failure of ideas negotiation or disintegration of a group, especially in the large-size classroom (Zurita \& Nussbaum, 2004; Borge \& White, 2016). 


\section{Shared Authority among Teachers and Students}

In a passive learning classroom, teachers do most of the instructional planning. In contrast, the collaborative classroom encourages the teachers to share authority with students more. Shared procedures with students make them be part of the instructional designs. The teachers should enable students to share their interests and engage in the decision-making process. It also benefits the differentiation in the classroom (Tinzmann et al., 1990). Each student needs to hold accountable for their responsibility. The students should be more active in exchanging opinions and give helpful feedback to a group to share their authority more effectively (Ibrahim et al., 2015).

Nonetheless, students sometimes feel not safe sharing their ideas with the community or making mistakes, especially in a large class with little collaborative experience (Borge \& White, 2016). Thus, the teachers need to have effective orchestration for better positive outcomes. Wellplanned management can promote more collaborative learning, especially implementing learning activities in real-world contexts (Borge \& Mercier, 2019).

\section{Teachers as Mediators}

Teachers in a collaborative classroom should emphasize mediated learning. The teachers should prepare students to explore learning through various concepts and assist in how they will know. Effective mediation should lead to a better connection of existing knowledge and new ideas (Tinzmann et al., 1990). As being mediator, a teacher should guide, facilitate, and provide positive feedback and support to students to learn so they are encouraged to freely work with enthusiasm (Ibrahim et al., 2015). Nonetheless, some issues typically arise in the collaborative classroom, such as negative social interaction and off-task behavior, especially in a large class (Borge \& White, 2016). This way, besides being mediators in learning, the teachers should oversee the classroom environment as well

\section{Heterogeneous Groupings of Students}

The diversity in a collaborative classroom allows students to perceive different and valuable ideas and solutions to problems. It is due to the differences in experiences, backgrounds, and attitudes. The teachers can provide some exciting contexts for students to explore new concepts. Meanwhiles, the students can share their thoughts and exchange information within a classroom (Tinzmann et al., 1990). The strengths of each student in the heterogeneous groups can culminate in the success of the group. Not only can the students produce favorable results, but they might also be proud and satisfy with themselves more (Ibrahim et al., 2015). Heterogeneity in learning groups aimed to improve academic achievements (Graf \& Bekele, 2006). If the teachers manage the heterogeneous groups effectively, the students should also achieve their educational goals (Kapur, 2020). However, more competent students may block other weaker students learning (Tinzmann et al., 1990). This way, the teachers should find practical tools to use in the collaborative classroom that assist students in working together and participating equally. 


\section{Advance Organizer Model}

Orientation to the model, Ausubel (1968) introduces this method as an effective way to convey ample information to students in a meaningful way. It mainly presents ideas that link to the particular concepts of the new learning. There are three phases of the advance organizer model syntax (Joyce et al., 2015):

\section{Phase 1: Presentation of Advance Organizer}

The teacher should obtain the attention of the students by clarifying the learning goals of the lessons. Advance organizers should recall information about students' existing knowledge. It is not the introductory comments at the beginning of the class. Instead, the models should give them a context or orientation to the subject presentation. It builds around the propositions or principle concepts of the area of study. It should scaffold the ideas of learners to a higher level of abstraction.

\section{Phase 2: Presentation of Learning Task or Material}

The teacher must point out the essential concepts to explain carefully. The advance organizers model should present as tasks or learning materials. The presentation should be clear to understand. It should show a link from a fundamental to a more advanced concept. New knowledge should be relevant to the previous command. It can present in form of lectures, discussions, tasks, reading, or experiments.

\section{Phase 3: Strengthening Cognitive Organization}

The new knowledge should anchor in the existing cognitive structure of the students There are four activities: 1) using principles of integrative reconciliation, 2) promoting active reception learning, 3) eliciting a critical approach to the subject matter, and 4) clarification.

According to Mohammadi, Moenikia, and Zahed-Babelan (2010), advance organizers can have a significant effect on the acquisition of knowledge, especially in the second language. They argue that graphic advance organizers significantly promoted English language learning as a second language, revealed from the pre-test and post-test scores. It claims that the organizer could help to organize information and ideas as it facilitates thinking processes while organizing and classifying new concepts. Moreover, it can also be a language tool that allows students to exercise language

Raj (2013) has studied a study on the effect of the Advance Organizer Model in the teaching of mathematics among secondary school pupils at differing levels of intelligence. The detailed analysis of the instructional effects and the nurturant effects present as follows (Raj, 2013; Joyce et al., 2015) 
Instructional Effects

Conceptual Structures

The model focuses on knowledge construction through students' cognitive structure. The concepts arise from lower-order to higher-order abstract. The idea is the symbolic construction used in thinking which can construct when a student responds to various stimuli in the same category or classification. The teacher should induce students to enlarge their conceptual system to proceed with the information.

\section{Meaningful Assimilation of Information and Ideas}

Meaningful learning depends on the effective presentation of information. It should help students retain the knowledge over a long time. The organization of knowledge and pedagogical function works paralleled. Meaningful assimilation requires a solid connection of the new learning material and existing ideas in the students' cognitive system. Students' cognitive structure must be prepared to comprehend and imply the new learning set, instead of memorization. When teachers input unfamiliar concepts to students, they will reconcile ideas from their similar or contrasting experiences. Then, they will construct their frame of reference and terminology. Hence, the teacher should facilitate these active cognitive operations to play an active role in this information processing system.

\section{Nurturant effects}

Interest in Inquiry

Link to the instructional effects, the students should develop the interest of inquiry spontaneously. It views that while students attempt to learn new materials, they know to inquire about methods to solve the contradiction between old and new concepts. The interest of inquiry would help them to investigate the information. Accordingly, they can generate and validate the information to newly constructed knowledge.

\section{Habits of Precise Thinking}

It refers to the behavioral pattern engaging in the information arrangement in the pattern or new information addition that can be related to the pattern.

\section{Meaningful Learning of New Concepts for ESL Learners}

The meaningful learning of concepts refers to how students can process the cognitive structure to connect their new learning to their existing knowledge (Joyce et al., 2015). The connection is likely to be less confused if similar information store in long-term memory (Ellis \& Hunt, 1983). According to Sharan (2015), meaningful learning depends on more than what teachers transmit. It advances the development of information out of students' understanding, experiences, and trades with different students. Additionally, students must apply the knowledge in higher-level and connect to their life meaningfully. It deals with the three major questions: 1) how knowledge is organized, 2) how students' cognitive process works while learning new 
information, and 3) how can a teacher design curriculum and instruction to apply these ideas of presenting new information (Joyce et al., 2015).

It connects to Bloom's taxonomy which shows the six stages of learning from lower-order thinking to higher-order thinking (Bloom, Engelhart, \& Furst, 1956; Deller, 2019). The taxonomy classifies the learning levels from remembering, comprehension, application, analysis, evaluation, and creation, which connect to the facet of understanding, having self-knowledge. New ideas construction from things you learned requires a complex comprehension. It is not just the context learning, but also the relationships of each element within the context. Learners should be able to synergize and integrate multi-knowledge to create new knowledge. It shows they have self-knowledge.

\section{Methods}

This study adopted the mixed-methods embedded experimental research design (Creswell \& Clark, 2011). The researcher employed both quantitative and qualitative methods to follow the two objectives. An observation and post-test integrated to examine the effects of using an advance organizer model to influence the meaningful learning of new concepts for ESL learners in a collaborative class.

\section{Participants}

The researcher conducted the study at the Mahidol University International School, Thailand. The population was the Business Studies students who are in grade 12th in the class of 2020. They were purposively selected to 20 students in a class of the Introduction to Skills for Leadership and Management. Students had mixed backgrounds in English proficiency range from $\mathrm{B} 1$ to $\mathrm{C} 1$. They also had different business backgrounds as some of them had studied other business electives previously, while the others had not.

\section{Research Instruments}

Post-test

The post-test is an evaluation tool to assess how students learn the new concepts of the lesson. The test has two parts with three questions. In the first part, the researcher uses a comparative organizer in table form to ask the student to compare the learning concepts. This part mainly focuses on comprehension and application of the concepts present in lower-order thinking. In the second part, there is one long answer question that students have to analyze and synthesize the concepts they have learned and give examples linking to their experiences from various situations.

\section{Observation Form}

The observation was a part of ongoing monitoring. At the beginning of a lesson, It was to monitor how teachers use advance organizer models. The observation form focuses to observe four domains: 1) planning and preparation, 2) the instructional environment, and 3) Instruction. 
Arab World English Journal (AWEJ) Volume 12. Number 3. September 2021

Using Advance Organizer Model to Influence the Meaningful Learning

Sunasuan \& Songserm

The observation also summarizes the ongoing activity, including commendations and recommendations in narrative writing format.

\section{Research Procedures}

To study the effects of using the advance organizer model, the researchers applied the instructional system design model, ADDIE model (Kruse, 2009), to design an instructional plan. There are five processes as follows.

Table 1. Steps of research design

\begin{tabular}{|c|c|c|}
\hline $\begin{array}{l}\text { ADDIE model } \\
\text { (Kruse, 2009) }\end{array}$ & \multicolumn{2}{|c|}{ Research procedures } \\
\hline $\begin{array}{l}\text { Analysis: The researcher collects } \\
\text { adequate data to analyze the gap } \\
\text { between the target outcomes and } \\
\text { the current situation }\end{array}$ & \multicolumn{2}{|c|}{$\begin{array}{l}\text { The researcher identified the need from Business studies standards and school } \\
\text { survey results. The study of relevant theories and researches aimed to design the } \\
\text { effective lessons of using advance organizer models to influence the meaningful } \\
\text { learning of new concepts for ESL learners in a collaborative classroom. }\end{array}$} \\
\hline \multirow{5}{*}{$\begin{array}{l}\text { Design: In this phase, the } \\
\text { researcher designs objects, } \\
\text { instruments, specific content, or } \\
\text { objectives. }\end{array}$} & \multicolumn{2}{|c|}{$\begin{array}{l}\text { The researcher designed content materials. The three phrases of the advance } \\
\text { organizer model syntax presented four lesson plans. }\end{array}$} \\
\hline & $\begin{array}{l}\text { Lesson } 1 \\
\text { (Phrase 1: } \\
\text { Presentation } \\
\text { of Advance } \\
\text { Organizer) }\end{array}$ & $\begin{array}{l}\text { Clarifying the aims of the lesson } \\
\text { Presenting advance organizer: } \\
\text { Identify defining attributes } \\
\text { Give examples } \\
\text { Provide context } \\
\text { Prompting awareness of learners relevant } \\
\text { knowledge and experience }\end{array}$ \\
\hline & $\begin{array}{l}\text { Lesson } 2 \\
\text { (Phase 2: } \\
\text { Presentation } \\
\text { of Learning } \\
\text { Task or } \\
\text { Material) }\end{array}$ & $\begin{array}{l}\text { Group work assignment: Assigning a concept to every two } \\
\text { groups. Each group discussing and completing a worksheet } \\
\text { Presenting material } \\
\text { Maintaining attention } \\
\text { Making organization explicit } \\
\text { Making logical order of learning material explicit }\end{array}$ \\
\hline & $\begin{array}{l}\text { Lesson } 3 \\
\text { (Phase 3: } \\
\text { Strengthening } \\
\text { Cognitive } \\
\text { Organization) }\end{array}$ & $\begin{array}{l}\text { Group work assignment: The two groups with the same new } \\
\text { concepts sharing discussion results and planning to share the } \\
\text { new idea with the other groups. } \\
\text { Peer teaching: Each group presenting the work. } \\
\text { Using principles of integrative reconciliation } \\
\text { Promoting active reception learning } \\
\text { Eliciting critical approach to the subject matter } \\
\text { Clarifying: Listeners asking questions to the } \\
\text { presenters to explain the new concepts }\end{array}$ \\
\hline & Lesson 4: & Post-test \\
\hline $\begin{array}{l}\text { Development: The researcher } \\
\text { creates the materials }\end{array}$ & \multicolumn{2}{|c|}{$\begin{array}{l}\text { The researcher developed the learning materials. There are lesson plans, } \\
\text { observation forms, post-test. }\end{array}$} \\
\hline $\begin{array}{l}\text { Implementation: The researcher } \\
\text { implements the output learning } \\
\text { materials in the sample group or } \\
\text { the target group. }\end{array}$ & \multicolumn{2}{|c|}{$\begin{array}{l}\text { The researcher implemented the output learning materials in the sample group } \\
\text { of } 20 \text { students in the class, the year 2020, at the Mahidol University } \\
\text { International Demonstration School, Thailand. }\end{array}$} \\
\hline $\begin{array}{l}\text { Evaluation: The researcher } \\
\text { evaluates the effectiveness of the } \\
\text { materials }\end{array}$ & \multicolumn{2}{|c|}{ The researcher evaluates the effects of the advance organizer model. } \\
\hline
\end{tabular}


The researchers used both formative and summative assessments. The participants took the post-test in the final lesson. The Deputy Director of Academics at Mahidol University International Demonstration School used the observation form during the instructional observation.

\section{Results}

The effects of the advance organizer model are as follows.

\section{The findings from studying the effects of using the advance organizer model}

Regarding the data obtained from the observation form, the results show that the advance organizer model can influence the meaningful learning of new concepts for ESL learners in collaborative classrooms. The content analysis present as follows.

\section{Instructional Effects}

\section{Conceptual Structures}

Observation results: It is a well-organized class in terms of an opening activity (review), new information, practice, independent application, and assessment. The teacher clarified the learning goals. The teacher had designed tasks to recall the students' existing knowledge and drive higher-order thinking. The teacher had pointed out essential concepts to be explained carefully. The teacher applied advance organizers as tasks and learning materials.

\section{Meaningful Assimilation of Information and Ideas}

Observation results: Overall, all students worked and found enough was unique in each of their roles. The teacher demonstrated the ability to translate learning goals into meaningful and relevant learning experiences. Students were able to explain the new concepts to peers, using examples from their experiences and answering questions with understanding. The analysis questions are very well, in that they move up Bloom's Taxonomy in terms of sophistication.

\section{Nurturant Effects}

\section{Interest in Inquiry}

Observation results: Students had developed an interest in the inquiry. Students had a chance to use more communication skills to read, write, listen and speak among peers when they were working on the projects in the group. The teacher was readily available to the students during the whole process, and students were comfortable asking questions and garnering other assistance during this lesson. Peers were motivated to acquire more information and pay more attention.

\section{Habits of Precise Thinking}

Observation results: Students engage in discussion effectively. The teacher strengthens how students connect their learning of new concepts and existing knowledge. The organization, in particular, spoke to the types of questions students should grapple with if they are developing their critical thinking skills. 


\section{The findings from studying the student achievement after using the advance organizer model to compare to the 80 percent criterion}

From implementing the lesson plans by using the advance organizer model to influence the meaningful learning of new concepts for ESL learners in a collaborative classroom, the students answered three questions that align with the concepts of meaningful assimilation of information and concepts. The results present in Table two.

Table 2. Findings from post-test

\begin{tabular}{|l|l|l|l|l|l|}
\hline Scores & $\mathrm{N}$ & Full score & Mean & Percent & S.D. \\
\hline After using & 20 & 26 & 21.5 & 82.69 & 3.16 \\
\hline
\end{tabular}

From the table, the student achievement after using the advance organizer model meets the criteria of 80 .

Some students showed to connect the concepts of the new information meaningfully to their experiences. They can explain the new concept using the ideas from their experiences by giving examples of the situations in their life where they presented or acted to link the characteristics of the concepts. They could analyze their ideas by connecting them to the concepts they have learned from peers' presentations. The examples of answers to reflect the meaningful learning of new concepts is as the following.

Student A: I think that the coaching leadership style is the most effective one. As I am a person who likes to plan things out and very observing, I usually become the one who assigns role and task to my friends whom I think they have the potential to do the jobs and later give them a little input and support to their output. Not only that, but I also like to help motivate and encourage my friends too by being a coaching leader. Most of the work matched expectations, and most of the followers are valued, inspired, and consulted. For example, when I was in grade ten, one of the teachers has assigned a group project to us. At that time, most people in my group did not have the idea. They could not come up with a way to present the data. Hence, I decided to stand up and assign each role to them by seeing what they are good at and support them.

Student B: For me, coaching is the best leadership style. It is because I can motivate people and provide direction simultaneously. There is one friend of mine who does not like to work. I tried to encourage him and give him what he can do for the job. My style of talking can be considered as motivated (one-on-one conversation), which suits this style. Also, my friend tells me that he does not know what to do. I will give him direction and provide support as he goes.

Student C: In my opinion, my most effective leadership style is supporting. I realize that when people ask me for suggestions, I am always willing to help them. I am a good listener, and I am 
never bored listening. As I did 16 characteristics, the result showed that I am likely to be a supporter. When I give them advice, they always tell me that it is helpful. As a supporting leadership style, it is highly supporting but lowly directing. Working in a group, I do not usually force people to do work that I assign, but I mostly ask they are willing to do work instead. When someone does the job not quite well, I will motivate and support them. I do not want to force anybody. When we have to come up with an idea in a group, I noticed that someone was afraid to share their ideas, so I will tell them to share that idea. effectively.

Overall, the students can link the new concept to their own experiences and values

\section{Discussion}

The effects showed in both instructional effects and nurturant effects. The students engaged in learning and acquiring information effectively. Students discussed and exchanged information using existing knowledge and experiences to connect and explain the ideas to others. The teacher planned, prepared, and instructed to meet the characters of collaborative classroom designs. The teacher facilitates and guides students with heterogeneous grouping effectively. The advance organizer is used in the lesson to help students develop conceptual structure. The instructional design also meets the steps of using an advance organizer model to influence the meaningful learning of new concepts for ESL learners in a collaborative classroom. The organization moved from lower-understanding context to higher-understanding context and allowed students to apply ideas from experiences.

Following Ellis and Hunt (1983), meaningful learning can occur if the new information can be associated with existing data. The teacher drives students learning from recall, connects previous knowledge, and uses the learning materials to influence meaningful learning in advanced abstracts link Bloom's Taxonomy ideas. According to Bloom (Bloom et al., 1956), the taxonomy is a significant model which classifies educational learning objectives into levels of complexity and specificity. It enhances student higher thinking and also guides educators on the design of curricula and examinations.

The post-test score is $82.69 \%$ which meets the $80 \%$ criterion assumption. It reflects that students can learn the concepts meaningfully. They met all the characteristics of meaningful assimilation of information and ideas. Students can link the previous knowledge to their new concepts. It showed that they have a comprehension of the new concepts. They can apply the ideas to solve the contradictory meanings and link them to their personal experiences. The posttest answers also reflected that the students could analyze and synthesize the concepts they learn to connect to their situations and values. 
This result complies with the finding of Mohammadi et al. (2010) that the advance organizer model can effectively promote student achievements, especially in the second language. Moreover, The characteristic of the collaborative classroom also supports the use of the organizer model, whereas heterogeneous grouping can improve academic achievements from greater participation in the lessons (Graf \& Bekele, 2006; Kapur, 2020).

\section{Conclusion}

This study investigated the effects of using the advance organizers model. The findings indicated that the advance organizer could enhance student learning of new concepts and create meaningful learning to meet high test scores. The qualitative data analysis revealed that ESL students benefit from the advance organizer model in a collaborative classroom. They can acquire knowledge to understand the new concepts in organized manners to follow the cognitive structure. Besides, students are more motivated to acquire new knowledge and confidence to share them. The advance organizer should use the questions that required the students to collaborate to answer several driving questions.

\section{Recommendation}

This study focused on influencing the meaningful learning of new concepts in Business studies for ESL learners in international schools who challenge both socially and emotionally as they have language barriers and present different perspectives. The advance organizer model can increase motivation to learn and link new concepts to their background effectively. The researcher would like to suggest any teachers implement the advance organizer model in the collaborative classroom. This strategy can break barriers for English language learners. It focuses less on teaching languages directly to build the students' understanding. The model can help the learning of new concepts. The students can enjoy the learning process more when it is relevant to their real-life situations. However, some studies had mentioned some known issues about collaborative learning in large classes, such as the disintegration of education, dominant leadership of more intelligent students, and fear of sharing personal ideas. Hence, further study should focus on implementing the advance organizer model in classes with more students to confirm its effectiveness.

\section{About the Authors:}

Piyawan Sunasuan is a Business Studies teacher at Mahidol University International Demonstration School, Thailand. She is currently a Ph.D. candidate at Silpakorn University in Thailand majoring in Curriculum and Instruction. Her research interests include instructional design and education for sustainable development. https://orcid.org/0000-0001-8024-5187

Assistant Professor Ubonwan Songserm, Ph.D. is a full-time lecturer at the Department of Curriculum and Instruction, Faculty of Education, Silpakorn University, Thailand. Her research areas include teaching methodology, model of teaching, learning theories and processes, and instructional system design. https://orcid.org/0000-0001-6452-4039 


\section{References}

Ausubel, D. P. (1962). A Subsumption Theory of Meaningful Verbal Learning and Retention. The Journal of General Psychology, 66, 213-224.

Ausubel, D. P. (1968). Educational Psychology: A Cognitive View. New York: Grune and Stratton. Bloom, B., Engelhart, M., \& Furst, E. (1956). Taxonomy of educational objectives: Handbook I. London: Longmans Green \& Co. Ltd.

Borge, M., \& Mercier, E. (2019). Towards a Micro-Ecological Approach to CSCL. International Journal of Computer-Supported Collaborative Learning, 14(1), 1-13. DOI: https://doi.org/14. 10.1007/s11412-019-09301-6

Borge, M., Ong, Y. S., \& Rosé, C. P. (2018). Learning to monitor and regulate collective thinking processes. International Journal of Computer-Supported Collaborative Learning, 13(1), 61-92. DOI: https://doi.org/10.1007/s11412-018-9270-5

Brown, B. L. (2001). Web-based training. Available at http://www.ericdigests.org/20012/training.html

Cohen, E. G. (1994). Restructuring the classroom: Conditions for productive small groups. Review of Educational Research, 64(1), 1-35. DOI: https://doi.org/10.3102/00346543064001001

Creswell, J. W., \& Plano, C. V. (2011). Designing and Conducting Mixed Methods Research (2nd ed.). Los Angeles: Sage Publications.

Deller, J. (2019). Bloom's Taxonomy Levels of Learning: The Complete Post. Available at https:/kodosurvey.com/blog/blooms-taxonomy-levels-learning-complete-post

Ellis, H. C., \& Hunt, R. R. (1983). Fundamentals of Human Memory and Cognition. Dubuque, Iowa: Brown.

Graf, S., \& Bekele, R. (2006). Forming Heterogeneous Groups for Intelligent Collaborative Learning Systems with Ant Colony Optimization. In Ikeda, M., Ashley, K. D., \& Chan, T. W. (eds.), Intelligent Tutoring Systems. (pp. 217-226). Springer, Berlin, Heidelberg. DOI: https://doi.org/10.1007/11774303_22

Ibrahim, N. et al. (2015). The Importance of Implementing Collaborative Learning in the English as a Second Language (ESL) Classroom in Malaysia. Procedia Economics and Finance, 31, 346-353. DOI: https://doi.org/10.1016/S2212-5671(15)01208-3

Independent Committee for Education Reform. (2019). patirūp kānsuksā Thai [Thai education reform]. Retrieved from https://www.thaiedreform.org/wpcontent/uploads/2019/06/CommissionReport050662.pdf

Johnson, D. W., \& Johnson, R. T. (1989). Cooperation and competition: theory and research. Edina, MN: Interaction Book Company.

Joyce, B. R., Weil, M., \& Calhoun, E. (2015). Models of Teaching (9th ed.). New Jersey: Pearson Education.

Kapur, R. (2020). Dealing with Heterogeneous Groups in Classrooms. Available at https:/www.researchgate.net/publication/345713296_Dealing_with_Heterogeneous_Grou ps_in_Classrooms 
Kruse, K. (2009). Introduction to Instructional Design and the ADDIE Model. Retrieved from https:/pdfs.semanticscholar.org/9dde/73651c087216677a930f1f5c2df02de6a5f9.pdf

Liang, X., Mohan, B. A., \& Early, M. (1998). Issues of Cooperative Learning in ESL Classes: A Literature Review. TESL CANADA JOURNAULA REVUE TESL DU CANADA, 15(2), 1323. DOI: https://doi.org/10.18806/tesl.v15i2.698

Luther, A. (2000). The "Old" Method of Teaching Vs. the "New" Method of Teaching. Journal of Thought, 35 (2), 59-69. Retrieved from http://Www.jstor.org/stable/42589616

Mercier, E., \& Higgins, S. E. (2015). The four Ts of the collaborative classroom. CEUR Workshop Proceedings, 1411, 15-19.

Mohammadi, M., Moeinikia, M., \& Zahed, A. (2010). The role of advance organizer on English language learning as a second language. Procedia - Social and Behavioral Sciences, 2, 4667-4671. DOI: 10.1016/j.sbspro.2010.03.747

Raj, S. M. (2013). A study on the effectiveness of Advance Organiser Model in the teaching of mathematics among secondary school pupils at differing levels of intelligence, (Unpublished PhD Thesis) Mahatma Gandhi University, Department of Education, Available at http:/hdl.handle.net/10603/7088

Shafie, L. A., Maesin, A., Osman, N., Nayan, S., \& Mansor, M. (2010). Studies in Literature and Language. Understanding Collaborative Academic Writing Among Beginner University Writers in Malaysia, 1(2), 58-69. DOI: http://dx.doi.org/10.3968/n

Sharan, Y. (2015). Meaningful learning in the cooperative classroom. Education, 43(1), 83-94. DOI: https://doi.org/10.1080/03004279.2015.961723

Sirithanyarat, C., \& Laoriendee, W. (2019). Instructional System Design (2nd ed.). Nakhon Pathom: Silpakorn University Printing house.

Slavin, R. E. (1995). Cooperative learning: Theory, research, and practice (2nd ed.). Boston, MA: Allyn and Bacon.

Tan, G., Gallo, P. B., Jacobs, G. M., \& Lee, C. K. (1999). Using Cooperative Learning to Integrate Thinking and Information Technology in a Content-Based Writing Lesson. The Internet TESL Journal, $V$, (8), 13-21. Retrieve from http:/iteslj.org/Techniques/TanCooperative.html

Tinzmann, M. B. et al. (1990). What Is the Collaborative Classroom? Oak Brook, Available at https://Www.researchgate.net/publication/251574844_What_Is_the_Collaborative_Classro om

Zurita, G., \& Nussbaum, M. (2004). Computer supported collaborative learning using wirelessly interconnected handheld computers. Computers \& Education, 42(3), 289-314. DOI: 10.1016/j.compedu.2003.08.005 